\title{
Active polylactic acid film incorporated with green tea extract: Development, characterization and effectiveness
}

\author{
Cristiana Martins $^{\mathrm{a}, 1}$, Fernanda Vilarinho ${ }^{\mathrm{b}, 1}$, Ana Sanches Silva ${ }^{\mathrm{c}, \mathrm{d}, *}$, Mariana Andrade ${ }^{\mathrm{b}}$, \\ Ana V. Machado ${ }^{\mathrm{e}}$, M. Conceição Castilho ${ }^{\mathrm{a}}$, Arsénio Sáe ${ }^{\mathrm{e}}$ Américo Cunha ${ }^{\mathrm{e}}$, M. Fátima Vaz \\ Fernando Ramos ${ }^{\mathrm{a}, \mathrm{g}}$ \\ a Faculdade de Farmácia, Universidade de Coimbra, Coimbra, Portugal \\ ${ }^{\mathrm{b}}$ Instituto Nacional de Saúde Doutor Ricardo Jorge, I.P., Lisboa, Portugal \\ ${ }^{\mathrm{c}}$ Instituto Nacional de Investigação Agrária e Veterinária, (INIAV), I.P., Vairão, Vila do Conde, Portugal \\ ${ }^{\mathrm{d}}$ Centro de Estudos de Ciência Animal (CECA), Universidade do Porto, Porto, Portugal \\ e Instituto de Polímeros e Compósitos/I3N, Universidade do Minho, Campus de Azurém, Guimarães, Portugal \\ ${ }^{\mathrm{f}}$ IDMEC, Instituto Superior Técnico, Departamento de Engenharia Mecânica, Universidade do Lisboa, Lisboa, Portugal \\ ${ }^{g}$ REQUIMTE/LAQV (Rede de Química e Tecnologia/Laboratório Associado para a Química Verde), Faculdade de Farmácia da Universidade de Coimbra, Azinhaga de \\ Santa Comba, 3000-548, Coimbra, Portugal
}

\section{A R T I C L E I N F O}

\section{Keywords:}

Active packaging

Polylactic acid

Green tea extract

Antioxidant capacity

Smoked salmon

Lipid oxidation

\begin{abstract}
A B S T R A C T
A new antioxidant active packaging film has been developed based on polylactic acid (PLA) in which green tea extract (GTE) has been immobilized by extrusion. Two GTE concentrations were tested, $1 \%(\mathrm{w} / \mathrm{w}$ ) and $2 \%(\mathrm{w} /$ w). Four GT samples were compared regarding their antioxidant capacity (by DPPH radical scavenging method and $\beta$-carotene bleaching method), total phenolics content (TPC) and total flavonoids content (TFC). The commercial GTE presented with highest antioxidant capacity by the DPPH radical assay $\left(\mathrm{EC}_{50}=0.12 \pm 0.00 \mathrm{mg} / \mathrm{mL}\right)$ and the highest TPC $(416 \pm 9.95 \mathrm{mg}$ gallic acid equivalents (GAE)/g extract) and it was selected to be incorporated in the active film. Films were evaluated regarding their mechanical properties (e.g. tensile strength decreased $12 \%$ with the incorporation of GTE in the PLA matrix and strain at break increased 9.6 and $36 \%$ with the addition of 1 and $2 \%$ of GTE) and water vapour transmission rates (watervapour barrier properties improved with the addition of higher amounts of GTE).

The study of the effectiveness of PLA/GTE films against lipid oxidation was performed by the following methods: peroxide value, $p$-anisidine value, thiobarbituric acid reactive substances (TBARS) assay and hexanal monitoring, after packaging smoked salmon slices during different storage times (0, 7, 15, 30, 45 and 60 days). The results showed that the incorporation of GTE in the PLA films protects the smoked salmon from lipid oxidation in the different storage times tested. However, additional studies should be performed to better understand the GTE mechanism of action as the results suggest a pro-oxidant effect of PLA/GTE $2 \%$ after 60 days of storage and to evaluate the potential antimicrobial activity of active films.
\end{abstract}

\section{Introduction}

The packaging allows preserving the safety and quality of food during storage, transportation, and above all, to prolong the shelf life of the food, avoiding unfavourable factors or conditions, such as deteriorating microorganisms, chemical contaminants, oxygen, moisture, light, external forces, among others (Yam et al., 2005; Marsh and Bugusu, 2007).

The use of biomaterials for food packaging is considered an environmentally friendly alternative, since it reduces the use of plastics from non-renewable resources or non-biodegradable and their accumulation in the environment (Jamshidian et al., 2010). PLA is produced from L-lactic acid, that is derived from the fermentation of corn or sugar beet. One of its main characteristics is to be biodegradable (Paul et al., 2003).

Changes in consumers' preference for safer, healthier and more convenient foods have led to innovations in packaging technologies. In this context, the concept of active packaging emerged, based on the

\footnotetext{
* Corresponding author at: Instituto Nacional de Investigação Agrária e Veterinária, (INIAV), I.P., Vairão, Vila do Conde, Portugal

E-mail address: ana.silva@iniav.pt (A. Sanches Silva).

${ }^{1}$ Authors contributed equality for this paper.
} 
positive interaction between the packaging and the food or its environment, in order to provide them with active protection (Biji et al., 2015). This is opposite to the main safety feature of conventional packaging intended to come into contact with food, which is to be as inert as possible (Silva et al., 2008; Sanches Silva et al., 2009). According to Regulation (EC) No. 1935/2004/EC (2004) and Regulation (EC) No. 450/2009 (2009), "active materials and articles are intended to extend the shelf life or to maintain or improve the condition of packaged food". They are designed to deliberately incorporate substances that can be released or absorbed into or from the packaged food or environment surrounding the food (Biji et al., 2015). In this sense, and seeking to satisfy the high concerns about consumer health and environmental problems, research on this type of packaging is currently focused on the use of natural components and biodegradable packaging materials (Carrizo et al., 2014). Some of these biodegradable polymers are also edible such as soy protein (Yu et al., 2018); cassava starch (Assis et al., 2017) and whey protein (Ribeiro-Santos et al., 2017). Substances with antioxidant or antimicrobial potential are available from a variety of natural sources, namely aromatic plants, fruits and vegetables (Yang et al., 2016a,b; Crizel et al., 2016; Cardoso et al., 2017).

Green tea is obtained from the leaves of Camelia sinensis L. and it is recognised by its antioxidant, antimicrobial, anticarcinogenic and antiinflammatory properties (Basnet et al., 2015; Perumalla and Hettiarachchy, 2011). Green tea is a rich source of polyphenol antioxidants, particularly catechins. GTE also contains other compounds, such as flavonoids and phenolic acids but in lower proportion (Lorenzo and Munekata, 2016). The GTE is reported to have antioxidant capacity, the main compounds responsible for this antioxidant capacity are gallic acid and eight major catechins: (+)-catechin (C), (-)-epicatechin (EC), (-)-catechin gallate (CG), (-)-epicatechin gallate (ECG), (-)-gallocatechin (GC), (-)-epigallo- catechin (EGC), (-)-gallocatechin gallate (GCG), and (-)-epigallocatechin gallate (EGCG) (López de Dicastillo et al., 2011).

Green tea extracts have already been incorporated in different polymeric matrices. For instance to polyethylene (López de Dicastillo et al., 2013); ethylene vinyl alcohol (López-de-Dicastillo et al., 2012; Muriel-Galet et al., 2015); agar and agar-gelatin (Giménez et al., 2013; López de Lacey et al., 2014); silver carp skin gelatin (Wu et al., 2013); chitosan (Siripatrawan and Harte, 2010; Siripatrawan and Noipha, 2012); gelidium corneum-gelatin (Hong et al., 2009) and soy protein (Theivendran et al., 2006).

Most of the studies focused on the optimization of the production conditions of the GTE active films and on the evaluation of its physical properties (thickness, tensile strength, elongation at break, light transmission, transparency, water vapour permeability, water resistance, water solubility, thermal stability) (Giménez et al., 2013; Wu et al., 2013) or on the release of active compounds from the film to food simulants (López-de-Dicastillo et al., 2012; Giménez et al., 2013; Muriel-Galet et al., 2015), evaluation of antioxidant activity (Giménez et al., 2013; Siripatrawan and Harte, 2010; López de Dicastillo et al., 2013; Muriel-Galet et al., 2015) and antimicrobial activity (Giménez et al., 2013; Muriel-Galet et al., 2015). GTE has been applied as a preservative treatment or incorporated in food packaging to different food matrices aiming to extend its shelf-life. These matrices include pork loins (Hong et al., 2009), sardines (López-de-Dicastillo et al., 2012); turkey frankfurters (Theivendran et al., 2006), pork sausages (Siripatrawan and Noipha, 2012), hake fillets (López de Lacey et al., 2014) and fresh-cut lettuce (Martín-Diana et al., 2008). The emerging technological field of nanotechnology is already applied in the production of active films. Wrona et al. (2017) have successfully developed a new active film material based on hydroxypropyl-methylcellulose (HPMC) containing poly(lactic acid) (PLA) nanoparticles (NPs) loaded with antioxidant (AO) green tea extract (GTE). The physico-chemical properties of the films and the antioxidant capacity of the GTE released from the active films was studied. The results suggested that the material could potentially be used to extend the shelf life of high fat food products.

Fish, in particular salmon, is very perishable, therefore several treatments have been applied to extend their shelf life such as cooling, super chilling, freezing, use of modified atmosphere packaging, smoking, irradiation or new technologies such as cold plasma or high pressure treatment (Broekaert et al., 2017; Albertos et al., 2016; Lyu et al., 2018). Smoked Atlantic salmon (Salmo salar) is highly appreciated cold ready-to-eat food mainly due to its flavour, colour, taste and associated health benefits due to their omega 3 fatty acids and protein content (Sampels, 2013; Martinsdóttir et al., 2014). Active packaging has recently been applied to smoked salmon. Baek and Song (2018) applied Gracilaria vermiculophylla extract films containing zinc oxide nanoparticles and they were able to obtain antibacterial activity and low degree of oxidation. Albertos et al. (2016) developed an olive leaf gelatin film which significantly reduced the growth of Listeria monocytogenes over storage.

The aim of this paper was to produce a biodegradable active film based on PLA, by blown film extrusion, incorporated with GTE. The GTE was characterized regarding its antioxidant capacity, total phenolics content (TPC) and total flavonoids content (TFC) and compared with other three non-commercial GTE. The new film was evaluated regarding its mechanical properties, water vapour transmission and effectiveness to inhibit lipid oxidation of model food. Smoked salmon was selected due to be a much appreciated high-fat content food with considerable high value in the market. To our knowledge this is the first time that an active PLA film containing GTE is evaluated regarding mechanical and barrier properties as well as its effectiveness in inhibiting lipid oxidation of smoked salmon.

\section{Material and methods}

\subsection{Green tea samples}

Four green tea samples were compared, two of them consisted of dried leaves of Camellia sinensis L., another comprised whole green leaf powder, and finally the fourth sample was a commercial GTE. Two varieties of green tea were obtained from dried leaves (Hysson and Encosta de Bruma) of the brand Gorreana (Azores, Portugal). Hysson green tea is produced from the first three leaves of the tea plant (Camellia sinensis) which are harvested in July and August, while the green tea "Encosta da Bruma" is produced exclusively from the terminal bud and the first leaf of the plant of tea, grown on the highest ridge of the Gorreana tea plantation and it is harvested in late July and early August. These samples were purchased from the online store of the company Plantações de Chá Gorreana, Lda. Green tea in capsules was purchased on a commercial surface in the region of Coimbra, whiles the commercial extract (Batch L704906709), was acquired from MyProtein.

The samples were stored at room temperature and protected from light and moisture.

\subsection{Chemicals and reagents}

Methanol (analytical grade) was purchased from VWR Chemicals (Fontenay-sous-Bois, France). Methanol and sulfuric acid (HPLC grade), anhydrous sodium sulphate, isooctane, glacial acetic acid, trichloroacetic acid, orthophosphoric acid (all analytical grade), sodium carbonate, absolute ethanol, sodium hydroxide, chloroform, all were purchased from Merck (Darmstadt, Germany). 2,2-diphenyl-1-picrylhydrazyl (DPPH), 2,6-di-tert-butyl-4-methylphenol (BHT), 2-(1,1dimethylethyl)-1,4-benzenediol (TBHQ), (-)-epicatechin (purity $\geq 90 \%$ ), (-)-epigallocatechin gallate (purity $\geq 80 \%$ ), (-)-epigallocatechin gallate (purity $\geq 95 \%$ ), 6-hydroxy-2,5,7,8-tetramethylchroman2-carboxylic acid (Trolox) (purity 97\%), Tween 40 , linoleic acid, $\beta$ carotene, Phenol reagent Folin \& Ciocalteu`s, sodium nitrite, aluminium chloride, potassium iodide, soluble starch, $p$-anisidine, thiobarbituric 
acid, 2,4-DNPH, were all purchased from Sigma-Aldrich (Steinheim, Germany). n-hexane for spectroscopy was supplied from BDH Prolabo (Leuven, Belgium).

\subsection{Preparation and extraction of samples}

Dried leaves of green tea were subjected to a grinding and homogenization process using a crusher A320R Moulinette from Moulinex (France), followed by a sieving process. The sample of commercial green tea has not required this procedure due to be already acquired as powder. For the extraction, $5 g$ of sample was weighed in an analytical balance AG285 Mettler Toledo (Lisbon, Portugal), and submitted to a solid-liquid extraction with $50 \mathrm{~mL}$ of absolute ethanol, with stirring at $400 \mathrm{rpm}$ for $30 \mathrm{~min}$ at room temperature in a horizontal stirrer HS 501D from IKA ${ }^{\circ}$-Labortechnik (Staufen, Germany). The mixture was then centrifuged at $15^{\circ} \mathrm{C}$ for $15 \mathrm{~min}$ at $5000 \mathrm{~g}$ in a SIGMA centrifuge model 3-16 K from SIGMA Laborzentrifugen GmbH (Osterode, Germany). The supernatant was withdrawn into a pyriform flask and subjected to complete evaporation of the ethanol at $35^{\circ} \mathrm{C}$ via a rotary evaporator RE111 with a vacuum pump V-700 from BÜCHI (Flawil, Switzerland). With the aid of a spatula, the extract was withdrawn from the flask and stored.

\subsection{Determination of the antioxidant capacity of green tea extracts}

\subsubsection{DPPH radical scavenging method}

The method described by Moure et al. (2001) was applied, with a change in reaction time of the sample with the DPPH radical from 16 to $30 \mathrm{~min}$. Methanolic solutions of the GTE were prepared with a concentration of $0.1 \mathrm{mg} / \mathrm{mL}$. In the dark, $50 \mu \mathrm{l}$ of GTE solutions reacted with $2 \mathrm{~mL}$ of the methanolic DPPH solution (14.2 $\mu \mathrm{g} / \mathrm{mL}$ DPPH). $50 \mu \mathrm{l}$ of methanol was used as the control. The absorbance was measured at a wavelength of $515 \mathrm{~nm}$ after $30 \mathrm{~min}$ in a spectrophotometer U-3900 from Hitachi (Tokyo, Japan) with software U.V Solutions 3.0. Radical scavenging capacity was expressed as an inhibition percentage (\% IP) and calculated using the following equation:

$(\%) \mathrm{IP}=[(\mathrm{Ac}-\mathrm{As} 30) / \mathrm{Ac}] \times 100$

Where:

(\%) IP - Inhibition percentage of DPPH radical

Ac - Control Absorbance

As30 - Sample absorbance after $30 \mathrm{~min}$

After calculation of the inhibition percentage of DPPH radical, the antioxidant capacity was expressed in $\mathrm{mg}$ Trolox equivalents per $\mathrm{g}$ extract (mg TE/g extract) (Kuskoski et al., 2006) and $\mu \mathrm{M}$ Trolox equivalents per $g$ extract $(\mu \mathrm{M} \mathrm{TE} / \mathrm{g}$ extract). For this comparison, a calibration curve of Trolox was used.

The DPPH assay was performed for the synthetic antioxidants BHT and TBHQ and for the catechins: (-)-epicatechin (purity $\geq 90 \%$ ), (-)-epigallocatechin gallate (purity $\geq 80 \%$ ) and the (-)-epigallocatechin gallate (purity $\geq 95 \%$ ). The results are expressed as $\mu \mathrm{M}$ TE.

Afterwards, it was determined the necessary concentration of extract to capture $50 \%$ of the amount of DPPH free radicals present in the solution, i.e., the EC50 (concentration required to obtain a 50\% antioxidant effect) was determined for the different GTEs. For this purpose, five different concentration levels were prepared for each extract and each \% IP value was calculated. Thus, by interpolation in the \% IP versus concentration $(\mathrm{mg} / \mathrm{mL})$ curve, it was possible to calculate the concentrations, for each extract, that gave IP equal to $50 \%$.

\subsection{2. $\beta$-Carotene bleaching method}

The spectrophotometric method of Miller (Gutiérrez et al., 2006) based on the ability of the different extracts to decrease oxidative losses of $\beta$-carotene in a $\beta$-carotene/linoleic acid emulsion was used. A solution of $\beta$-carotene at a concentration of $0.2 \mathrm{mg} / \mathrm{mL}$ was prepared by dissolving $2 \mathrm{mg}$ of $\beta$-carotene in $10 \mathrm{~mL}$ of chloroform. In a round-bottomed flask, $200 \mathrm{mg}$ of Tween $40,20 \mathrm{mg}$ of linoleic acid and $1 \mathrm{~mL}$ of the $\beta$-carotene solution were added. Chloroform was evaporated at $40^{\circ} \mathrm{C}$ to 100 mbar in a rotary evaporator RE-111 with a vacuum pump V-700 from BÜCHI (Flawil, Switzerland). Then, $50 \mathrm{~mL}$ of oxygenated distilled water was added and the mixture was emulsified for $30 \mathrm{~min}$ in magnetic stirrer plate Agimatic 243 (Barcelona, Spain), to form a stable emulsion. Finally, $0.2 \mathrm{~mL}$ of sample reacted with $5 \mathrm{~mL}$ of the $\beta$-carotene emulsion at $50{ }^{\circ} \mathrm{C}$ for $2 \mathrm{~h}$ in a heating block SHT 1 from Stuart Scientific (Burlington, USA). For the control assays $0.2 \mathrm{~mL}$ of solvent was used. The absorbance of the control assays was measured at $470 \mathrm{~nm}$ before and after $2 \mathrm{~h}$ of reaction and the absorbance of the samples was measured only after $2 \mathrm{~h}$ at the same wavelength in a spectrophotometer $\mathrm{U}$ 3900 from Hitachi (Tokio, Japan). The Antioxidant Activity Coefficient (AAC) was calculated by the following equation:

$\mathrm{AAC}=[(\mathrm{AA} 120-\mathrm{Ac} 120) /(\mathrm{Ac0}-\mathrm{Ac} 120)] \times 1000$

Where:

AA 120 - the absorbance of the sample after 120 min of reaction

Ac 120 - the absorbance of the control assays after $120 \mathrm{~min}$ of reaction

Ac 0 - the absorbance of the control assays at the initial time

\subsection{Determination of total phenolics content}

The used method was adapted from the method of Erkan et al. (2008). $7.5 \mathrm{~mL}$ of Folin-Cioucalteau reagent (1:10, v/v) was added to an aliquot of $1 \mathrm{~mL}$ of sample. After $5 \mathrm{~min}, 7.5 \mathrm{~mL}$ of an aqueous solution of sodium carbonate $\left(\mathrm{Na}_{2} \mathrm{CO}_{3}, 6 \mathrm{mg} / \mathrm{mL}\right)$ was added. The solutions were kept in the dark for $120 \mathrm{~min}$. After this period, the absorbance was measured in a spectrophotometer U-3900 from Hitachi (Tokyo, Japan) at $725 \mathrm{~nm}$ against water as blank. The total phenolic contents were calculated on the basis of the calibration curve of gallic acid and expressed as gallic acid equivalents (GAE), in milligrams per gram of the sample. Quantification of total phenolic content was carried out for GTEs in ethanol, always in triplicate, and at a concentration of $0.1 \mathrm{mg}$ / $\mathrm{mL}$.

\subsection{Determination of total flavonoids content}

The used method was adapted from the method of Yoo et al. (2008). $1 \mathrm{~mL}$ of the sample was diluted with $4 \mathrm{~mL}$ of water. Then, $0.3 \mathrm{~mL}$ of $5 \%$ $\mathrm{NaNO}_{2}$ solution was added to the mixture. After $5 \mathrm{~min}, 0.6 \mathrm{~mL}$ of $10 \%$ $\mathrm{AlCl}_{3}$ solution was added. After $6 \mathrm{~min}, 2 \mathrm{~mL}$ of $1 \mathrm{M} \mathrm{NaOH}$ and $2.1 \mathrm{~mL}$ of distilled water was added, and the solution was homogenized. Absorbance of the mixture was determined at $510 \mathrm{~nm}$ against water as blank in a spectrophotometer U-3900 from Hitachi (Tokyo, Japan). The results were expressed as epicatechin equivalents per gram of sample (mg ECE/g sample). Quantification of total flavonoids compounds was performed for GTE in ethanol, always in triplicate, and at a concentration of $0.5 \mathrm{mg} / \mathrm{mL}$.

\subsection{PLA active packaging}

\subsubsection{Preparation of a PLA/GTE masterbatch}

Previous to blown film extrusion, a PLA/GTE masterbatch was produced to ensure better GTE dispersion in the PLA matrix during. Initially PLA (PLA pellets, Ingeo 4032D, Natureworks ${ }^{\mathrm{TM}}$, The density was $1.24 \mathrm{~g} / \mathrm{mL}$ and the melting point was $168^{\circ} \mathrm{C}$.) and GTE were dried at $80^{\circ} \mathrm{C}$, for $4 \mathrm{~h}$, in a vacuum oven. Thereafter, a masterbatch with approximately $8 \mathrm{wt} . \%$ of GTE was produced in a Leistritz AG LSM $346 \mathrm{~L}$ co-rotating twin screw extruder $190{ }^{\circ} \mathrm{C}$, with a screw speed of $100 \mathrm{rpm}$ and a flow rate of $1.5 \mathrm{~kg} / \mathrm{h}$.

The GTE degradation was minimized by its addition in a front part of the extruder through a secondary feed system. The mixture was 
extruded as filaments, cooled, dried and granulated.

\subsubsection{Blown film extrusion and fourier transform infrared spectroscopy} (FTIR)

The pristine PLA and the PLA/GTE masterbatch were dried before the extrusion at $60^{\circ} \mathrm{C}$, in a vacuum oven, overnight. Different amounts of masterbatch were added to PLA to produce films containing 1\% (w/ w) and $2 \%(\mathrm{w} / \mathrm{w})$ of GTE. A Periplast blown extruder, equipped with a single screw, was used to produce films of the PLA with GTE. The processing conditions were constant, screw speed of $50 \mathrm{rpm}, 170^{\circ} \mathrm{C}$ on the first heating zone and $175^{\circ} \mathrm{C}$ on the remaining zones.

Fourier transform infrared spectroscopy (FTIR) spectra were acquired using a 4100 Jasco spectrometer in the range of $4500-400 \mathrm{~cm}^{-1}$, by averaging 32 scans and using a resolution of $8 \mathrm{~cm}^{-1}$. Translucent thin films, prepared by compression molding in a hot press at $170{ }^{\circ} \mathrm{C}$ under a pressure of 10 tons, of masterbatch mixture and extruded films were used in the analysis. A translucent sample disc of GTE (10 wt.\% in $\mathrm{KBr},>99 \%$, Arcos organics) was used to acquire the FTIR spectrum.

\subsubsection{Mechanical properties}

The tensile properties of the films were determined at room temperature using a Zwick/Roell Z005 equipment, following the ASTM American Standard Testing and Material D 882 - 02 standard (2002).

The mechanical properties were determined using longitudinal specimen. Five specimens of each sample were prepared with $310 \times 20 \mathrm{~mm}$ and tested using an initial grip separation of $250 \mathrm{~mm}$ and an elongation rate of $25 \mathrm{~mm} / \mathrm{min}$. Stress/strain curves were used to determine yield stress ( $\sigma$ stress), yield strain ( $\varepsilon$ strain), tensile strength ( $\sigma$ strength), strain at break ( $\varepsilon$ break) and Young's modulus ( $\varepsilon$ young).

\subsubsection{Water vapour transmission}

The water vapour barrier properties of the extruded films were determined based on the ASTM E 96/E 96 M - 05 standard (2005). The desiccant method was used to determine the value of water vapour transmission (WVT). The films were placed in test dishes, with a surface diameter of $69.5 \mathrm{~mm}$, filled with approximately $25 \mathrm{~g}$ of $\mathrm{CaCl}_{2} \cdot 6 \mathrm{H}_{2} \mathrm{O}$ (extra pure calcium chloride hexahydrate, Riel de Haën), previously dried at $150^{\circ} \mathrm{C}$ in a vacuum oven. The assay was conducted at room temperature in triplicate. The weight was measure along the assay and until a relative humidity $(\mathrm{RH})$ of $10 \%$ has been achieved.

\subsection{Packaging of the smoked salmon}

The selected model food was smoked Atlantic salmon, due to the high content of polyunsaturated fatty acids present in its composition, susceptible to lipid oxidation. The smoked salmon was purchased, already sliced, on a commercial area of Lisbon. The smoked salmon information on nutritional composition (per $100 \mathrm{~g}$ of edible portion) was the following: 9.4 fat, from which $2.0 \mathrm{~g}$ were saturated fatty acids, $4.9 \mathrm{~g} / 100 \mathrm{~g}$ monounsaturated fatty acids, $2.5 \mathrm{~g}$ polyunsaturated fatty acids and $0.4 \mathrm{~g} \omega-3$ fatty acids, $23.1 \mathrm{~g}$ protein and $0.8 \mathrm{~g}$ carbohydrates. The label also indicated the content of salt to be $2.8 \mathrm{~g} / 100 \mathrm{~g}$. The commercially packed product was sealed in a vacuum pack and it presented a commercial validity of one month when acquired. Slices of smoked salmon of approximately $40 \mathrm{~g}$ were placed in direct contact (vacuum packaged) with PLA films with different concentrations of GTE $(1 \%(\mathrm{w} / \mathrm{w})$ and $2 \%(\mathrm{w} / \mathrm{w}))$, respectively, and with a PLA film without GTE (control film). Both sides of each smoked salmon slice were in contact with the film. The area of contact between the smoked salmon and the film was approximately $0.15 \mathrm{dm}^{2}$. Subsequently, they were packaged to allow good contact between the film and the model food. Smoked salmon slices were in contact with the films during different storage times $(7,15,30,45$ and 60 days), at refrigeration temperature $\left(5{ }^{\circ} \mathrm{C}\right)$ and in the dark.

\subsection{Effectiveness of the active films against lipid oxidation}

The lipid oxidation status of the smoked salmon slices was determined after each storage period $(0,7,15,30,45$ and 60 days). For this purpose, the following tests were carried out: peroxide value, $p$ anisidine value, TBARS assay and monitoring of hexanal.

\subsubsection{Fat extraction}

The assays, peroxide index and determination of the value of $p$ anisidine were performed with fat, so it was necessary to extract the fat from the smoked salmon slices packaged with the active films and the control film.

The used method was adapted from the method of Bligh-Dyer (Bligh and Dyer, 1959). To $30 \mathrm{~g}$ of homogeneized smoked salmon $150 \mathrm{~mL}$ of chloroform, $300 \mathrm{~mL}$ of methanol and $120 \mathrm{~mL}$ of ultrapure water (water purification system Milli-Q, Millipore Corp., Belford, USA) were added. Then, the solution was homogenized and stirred for $30 \mathrm{~min}$ in a homogenizer Ultra-Turrax IKA ${ }^{\circ}$ DI 25basic (Staufen, Germany) and, after, $150 \mathrm{~mL}$ of chloroform and $150 \mathrm{~mL}$ of the $1.5 \%$ anhydrous sodium sulphate solution were added. This solution was stirred for $2 \mathrm{~min}$ in a stirrer plate Agimatic 243 (Barcelona, Spain) and transferred to a separation funnel. After complete separation of the two phases, the chloroform was removed. The chloroform was filtered with a Whatman $\mathrm{n}^{\mathrm{o}} 4$ filter to which $1 \mathrm{~g}$ of anhydrous sodium sulphate was added to retain sample water. Chloroform was evaporated at $40{ }^{\circ} \mathrm{C}$ in a rotary evaporator Büchi model R-210 (Labortechnik, Switzerland). The fat obtained was conserved, protected from light, at $5{ }^{\circ} \mathrm{C}$.

\subsubsection{Peroxide value}

The methodology used to determine the peroxide value was adapted from the Cd8-53 method described by the American Society of Oils Chemists (AOCS, 2003).

To carry out this test, it is necessary to prepare a saturated solution of potassium iodide in ultrapure water, a starch solution and a $0.01 \mathrm{~N}$ sodium thiosulphate solution.

To prepare the starch solution, $0.5 \mathrm{~g}$ of starch were diluted in $10 \mathrm{~mL}$ of ultrapure water, to which $40 \mathrm{~mL}$ of warm ultrapure water was added. The solution was boiled for $3 \mathrm{~min}$ and rapidly cooled on ice. To $0.1 \mathrm{~g}$ of fat (extracted by the procedure described previously), $10 \mathrm{~mL}$ of isooctane, $15 \mathrm{~mL}$ of acetic acid and $1 \mathrm{~mL}$ of saturated potassium iodide solution were added. The solution was stirred for one minute and it was stored at room temperature, protected from light for $5 \mathrm{~min}$. After $5 \mathrm{~min}$, $3 \mathrm{~mL}$ of the starch solution and $75 \mathrm{~mL}$ of ultrapure water, were added. The solution was titrated with $0.01 \mathrm{~N}$ sodium thiosulfate solution until the solution turned white. For the control test, the same procedure was followed, however fat was not used. Samples were run in triplicate.

The determination of the peroxide value (PV) was calculated by the following equation:

$\mathrm{PV}\left(\mathrm{meqO}_{2} / \mathrm{Kg}\right.$ fat $)=[(\mathrm{S}-\mathrm{B}) \times \mathrm{N} \times 1000] / \mathrm{m}$

Where:

$\mathrm{S}$ - Volume of sodium thiosulphate $0.01 \mathrm{~N}$ used in the titration

$\mathrm{B}$ - Volume of $0.01 \mathrm{~N}$ sodium thiosulfate used in the control assay

$\mathrm{N}$ - Normality of sodium thiosulphate

$\mathrm{m}-$ Amount of fat $(\mathrm{g})$

\subsection{3. p-Anidisine value}

The determination of the $p$-anisidine value was performed according to the British Standard method BS 684-2.24-1998(BSI, 1998).

The $p$-anisidine value was calculated according to the following equation:

$\mathrm{AV}=25\left(1.2 \mathrm{Abs}_{2}-\mathrm{Abs}_{1}\right) / \mathrm{m}$

Where:

$\mathrm{AV}$ - value of $p$-anisidine 
Table 1

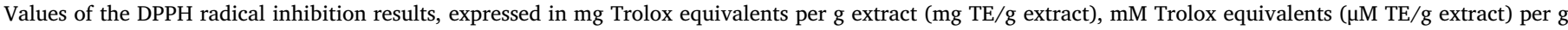

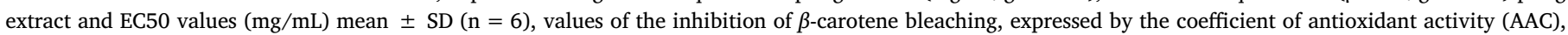
mean $\pm \mathrm{SD}, \mathrm{n}=6$.

\begin{tabular}{|c|c|c|c|c|}
\hline \multirow[t]{2}{*}{ GT Extract } & \multicolumn{3}{|l|}{ DPPH } & \multirow{2}{*}{$\begin{array}{l}\beta \text {-carotene bleaching } \\
\text { (AAC) }\end{array}$} \\
\hline & mg TE/g extract & $\mathrm{mM} \mathrm{TE} / \mathrm{g}$ extract & $\mathrm{EC} 50(\mathrm{mg} / \mathrm{mL})$ & \\
\hline Commercial GT & $0.917 \pm 0.09$ & $3.66 \pm 0.35$ & $0.12 \pm 0.00$ & $918 \pm 14.8$ \\
\hline GT from Capsules & $0.560 \pm 0.02$ & $2.24 \pm 0.09$ & - & $1079 \pm 8.98$ \\
\hline Hysson GT & $0.602 \pm 0.12$ & $2.40 \pm 0.50$ & $0.16 \pm 0.00$ & $1144 \pm 7.67$ \\
\hline Encosta da Bruma GT & $0.693 \pm 0.07$ & $2.77 \pm 0.30$ & $0.15 \pm 0.00$ & $1178 \pm 14.53$ \\
\hline
\end{tabular}

$\mathrm{Abs}_{2}$ - absorbance of the sample after 10 min of reaction

$\mathrm{Abs}_{1}$ - initial sample absorbance

$\mathrm{m}-$ amount of fat used in the test (in $\mathrm{g}$ )

$25 \mathrm{~mL}$ of $\mathrm{n}$-hexane was added to $0.5 \mathrm{~g}$ of fat (previously extracted) and the solution was placed 5-10 min. in the Ultrasonic Bath Branson Bransonic 3510 (Dietznbach, Germany) at room temperature until the fat was dissolved. Afterwards, $1 \mathrm{~mL}$ of the $p$-anisidine solution was added and it was stored in the dark for $10 \mathrm{~min}$ at room temperature. The absorbance of the solution was measured at $350 \mathrm{~nm}$ against $n$ hexane in a Hitachi U-2000 spectrophotometer, before the addition of the $p$-anidisine solution and after the $10 \mathrm{~min}$ reaction. For the control test, $1 \mathrm{~mL}$ of the solution of $p$-anisidine was added to $5 \mathrm{~mL}$ of $n$-hexane. At the end, the absorbance of the samples against the control test was measured. All analyzes were performed in triplicate.

\subsubsection{Thiobarbituric acid reactive substances (TBARS) assay}

According to the method of Miller (1998), TBARS assay was based on the spectrophotometric measurement of a complex formed by the reaction between thiobarbituric acid (TBA) and malondialdehyde (MDA) (formed as a result of the degradation of polyunsaturated fatty acids). $5 \mathrm{~g}$ of each sample (sliced smoked salmon crushed and homogenized) was weighed into a $100 \mathrm{~mL}$ beaker, to which $50 \mathrm{~mL}$ of the TCA solution was added. The solution was homogenized for $1 \mathrm{~min}$ at $8000 \mathrm{rpm}$ in a homogenizer Ultra-Turrax IKA ${ }^{\circ}$ DI 25basic (Staufen, Germany) and filtered (Whatman $\mathrm{n}^{\circ} 1$ filter) into a $50 \mathrm{~mL}$ flask. Then, $5 \mathrm{~mL}$ of the $0.02 \mathrm{M}$ TBA solution was added to $5 \mathrm{~mL}$ of the filtrate. For the control test, $5 \mathrm{~mL}$ of the TBA solution was added to $5 \mathrm{~mL}$ of ultrapure water. Subsequently, the samples were subjected to $100^{\circ} \mathrm{C}$ for $40 \mathrm{~min}$ in the heating block QBD2 Heating Block from Grant Instruments (Cambridge, England). After $40 \mathrm{~min}$, the samples were placed in an ice bath for $15 \mathrm{~min}$ to cool down completely. Finally, the absorbance of the samples on the spectrometer Hitachi U-2000 spectrophotometer at $530 \mathrm{~nm}$ was measured against the control test. All assays were performed in triplicate.

\subsubsection{Hexanal assay}

The preparation of the sample was carried out according to the methodology developed by Wen et al. (1997). The hexanal identification and quantification was performed according to the method developed by Ribeiro-Santos et al. (2017). Initially, a solution of 2,4DNPH was prepared $(0.17 \mathrm{~g}$ of 2,4-DNPH was weighed into a $100 \mathrm{~mL}$ flask and the volume was made up with a $30 \%$ aqueous solution of sulphuric acid (v/v)). For the hexanal extraction, $5 \mathrm{~mL}$ of the 2,4-DNPH solution were added to, $1 \mathrm{~g}$ of the smoked salmon and then homogenized at $8000 \mathrm{rpm}$ for $2 \mathrm{~min}$ in a homogenizer Ultra-Turrax IKA ${ }^{\circ} \mathrm{DI}$ 25basic (Staufen, Germany) at room temperature. Thereafter, the solution was held for $4 \mathrm{~h}$ in the dark at room temperature. After this time, $10 \mathrm{~mL}$ of $n$-hexane were added and the solution was centrifuged at $4000 \mathrm{rpm}$ for $10 \mathrm{~min}$ at $15^{\circ} \mathrm{C}$ in a Centrifuge Eppendorf AG model 5804R (Hamburg, Germany). The supernatant was removed to an evaporator flask and the process was repeated twice.

Subsequently, $n$-hexane was evaporated at $35^{\circ} \mathrm{C}$ in a rotary evaporator Büchi model R-210 (Labortechnik, Switzerland) and the residue redissolved in $10 \mathrm{~mL}$ of methanol. After filtration, the solution was analyzed in an Ultra-Performance Liquid Chromatography (UPLC ${ }^{\circ}$ ), ACQUITY ${ }^{\mathrm{Tm}}$ (Waters, Milford, MA, USA), with a Diode Array (DAD) detector, a binary pump, an automatic sampler and a thermostat system for the column, UPLC ${ }^{\oplus}$ BEH C18 analytical pre-column $(2.1 \times 5.0 \mathrm{~mm}$, $1.7 \mu \mathrm{m}$ particle size) (Waters, Milford, MA, USA), Analytical column ACQUITY UPLC ${ }^{\circ}$ BEH C18 $(2.1 \times 50 \mathrm{~mm}, 1.7 \mu \mathrm{m}$ particle size $)$, Empower $^{\mathrm{TM}}$ software version 2.0 (Waters, Milford, MA, USA). In this chromatographic method, the column was maintained at $20^{\circ} \mathrm{C}$, the mobile phase flow was $0.5 \mathrm{~mL} / \mathrm{min}$ and the injection volume was $10 \mu \mathrm{l}$. The hexanal was identified and quantified at $365 \mathrm{~nm}$, and the retention time was $0.95 \pm 0.1 \mathrm{~min}$. All analyzes were performed in triplicate.

\subsection{Statistical analysis}

Results were expressed as mean \pm standard deviations of at least three replicates. Differences among samples were tested using Kruskal Wallis followed by Mann Whitney. All statistical analyses were tested at 0.05 level of probability, using the SPSS ${ }^{\circ}$ computer programme (SPSS Inc., Chicago, IL, USA).

\section{Results and discussion}

\subsection{Determination of DPPH $\cdot$ radical scavenging and $\beta$-carotene bleaching}

The results of DPPH inhibition system assay are presented in Table 1. Besides the Trolox equivalents (TE) per gram of green tea extract, results are also presented as EC50, i.e., the necessary concentration of extract to capture $50 \%$ of the amount of DPPH free radicals present in the solution. The commercial GTE presented the highest antioxidant capacity $(0.92 \mathrm{mg} \mathrm{TE} / \mathrm{g}$ extract) followed by GTE from Encosta de Bruma green tea ( $0.70 \mathrm{mg}$ TE /g extract).

Table 1 also presented the results of the $\beta$-carotene bleaching test. Encosta de Bruma GTE was shown to have the highest antioxidant capacity among those evaluated.

Analysing the results obtained, it can be verified that in the DPPH inhibition test, the extract from GT capsules showed the lowest antioxidant capacity ( $056 \mathrm{mg} \mathrm{TE} / \mathrm{g}$ extract), whereas in the $\beta$-carotene bleaching test the extract that presented lower antioxidant capacity was the commercial extract (AAC $=918$ ).

In the studies published, which aim to analyze the antioxidant capacity among different plant extracts, there are few that study the antioxidant capacity of green tea extracts. For instance, Lorenzo et al. (2014) and Pateiro et al. (2014) reported the influence of some natural extracts (green tea, grape, chestnut and seaweed) in the shelf life of pork patties/pig pâtés. These authors reported the EC50 of the GTE used as $0.12 \mathrm{~g}$ extract/L, which corresponds to the EC50 of the commercial GTE evaluated in the present study.

Lee et al. (2014) has determined the major constituents in green tea and the antioxidant capacity by ABTS (2,2'-azinobis-(3-ethylbenzothiazoline-6-sulfonic acid), FRAP and DPPH assays. However, the results were presented as $\mathrm{mM} \mathrm{TE} / \mathrm{g}$ green tea instead of $\mathrm{mM} \mathrm{TE} / \mathrm{g}$ GTE, therefore compared with present results are not possible. 


\section{Table 2}

Comparison of the results of inhibition of DPPH radical, expressed as $\mu \mathrm{M}$ Trolox equivalent $(\mu \mathrm{M}$ TE), mean $\pm \mathrm{SD}(\mathrm{n}=2)$, for standard antioxidants $(0.1 \mathrm{mg} / \mathrm{mL})$ and different green tea extracts $(0.1 \mathrm{mg} / \mathrm{mL})$.

\begin{tabular}{ll}
\hline Standards/GTE & $\mu \mathrm{M}$ TE \\
\hline (-) - Epigallocatechin gallate $(\geq 95 \%)$ & $735 \pm 3.94$ \\
$(-)$ - Epigallocatechin gallate $(\geq 80 \%)$ & $734 \pm 13.1$ \\
(-) - Epicatechin $(\geq 90 \%)$ & $667 \pm 7.88$ \\
TBHQ & $741 \pm 5.00$ \\
Commercial GT & $366 \pm 35.4$ \\
GT from Capsules & $224 \pm 9.31$ \\
Hysson GT & $240 \pm 49.8$ \\
Encosta da Bruma GT & $277 \pm 29.8$ \\
\hline
\end{tabular}

Wu et al. (2013) prepared an active film from silver carp skin gelatin incorporated with GTE. The IP (\%) of a solution of $0.1 \mathrm{mg} / \mathrm{mL}$ of the extract used to prepared this film was in accordance with the IP (\%) of the GTE evaluated in the present study (29-45\%).

In the present study, it was also determined the antioxidant activity, by DPPH inhibition test, for some reference standards. The comparison among the antioxidant capacity obtained of standard antioxidants and GTE are described in Table 2. As expected, the synthetic antioxidant TBHQ and the evaluated catechins presented higher antioxidant capacity than the green tea extracts analyzed.

The order of the activity of the DPPH radical elimination of reference standards tested was the following: TBHQ $>(-)$-epigallocatechin gallate (purity $\geq 95 \%) \approx(-$ )-epigallocatechin gallate (purity $\geq 80 \%)>(-$ )-epicatechin (purity $\geq 90 \%$ ). The $(-)$-epigallocatechin gallate (purity $\geq 95 \%$ and purity $\geq 80 \%$ ) presented values of antioxidant activity very similar, (734.9 and $733.9 \mu \mathrm{M} \mathrm{TE})$, and higher than the (-)-epicatechin (purity $\geq 90 \%$ ), in accordance to Lee et al. (2014). The TBHQ presented approximately twice higher antioxidant activity than commercial GT and around 3 times higher antioxidant activity than the other evaluated GTE.

\subsection{Determination of content in total phenolic compounds and total flavonoids}

In plants, one of the main groups of compounds that act as primary antioxidants or free radical scavengers are the phenols (Hatami et al., 2014). The group of polyphenols, are extremely effective as oxygen scavengers, reducing agents and hydrogen donors (Hatami et al., 2014). In this study, a blue-coloured solution, due to the presence of phospho molybdic- phosphotungstic-phenol complex, was produced when the active extracts or fractions reacted with Folin-Ciocalteau reagent in an alkaline medium. The content of phenolics was calculated from the regression equation of the gallic acid calibration curve, $y=8.0578 x+0.0764$, with a coefficient of determination of 0.9993 , expressed in GAE as milligrams per gram of the extract or fraction (mg $\mathrm{GAE} / \mathrm{g}$ extract or fraction).

As far as total flavonoids are concerned, these are some of the main chemical antioxidant components, being potent metal chelators and inhibitors of lipoperoxidation (Peron et al., 2008). Flavonoids, including flavones, flavanols and condensed tannins, are plant secondary metabolites, and their antioxidant activity depends on the presence of free $\mathrm{OH}$ groups, especially $3-\mathrm{OH}$. Flavonoids have antioxidant activity in vitro and also act as antioxidants in vivo (Geetha et al., 2003). Epicatechin was used to construct the standard curve using six calibration points in a range of $0.025-0.150 \mathrm{mg} / \mathrm{mL}$, and the results are expressed as mg ECE equivalents per $\mathrm{g}$ of extract.

The assays mentioned were carried out for the four GTEs under study (Table 3).

Analyzing the results, it was verified that the commercial extract showed a higher content of total phenolic compounds (416 mg GAE/g extract), whereas the Hysson extract showed a higher content of total
Table 3

Values of the total phenolic compounds results, expressed in mg equivalents of gallic acid per $g$ extract (mg GAE/g extract), mean $\pm S D(n=6)$, and values of total flavonoids results, expressed as $\mathrm{mg}$ of epicatechin equivalent per $\mathrm{g}$ extract (mg ECE/g extract), mean \pm SD $(n=6)$.

\begin{tabular}{lll}
\hline Extract & $\begin{array}{l}\text { Total Phenolic Compounds } \\
\text { (mg GAE/g extract) }\end{array}$ & $\begin{array}{l}\text { Total Flavonoids } \\
\text { (mg ECE/g extract) }\end{array}$ \\
\hline Green tea Commercial & $416 \pm 9.95$ & $148 \pm 0.21$ \\
Green tea Capsules & $272 \pm 2.34$ & $139 \pm 9.59$ \\
Green tea Hysson & $330 \pm 4.68$ & $184 \pm 0.64$ \\
Green tea Encosta da Bruma & $361 \pm 3.22$ & $165 \pm 7.03$ \\
\hline
\end{tabular}

flavonoids (184 mg ECE/g extract).

In the literature, there are several studies in which the contents of total phenolic compounds and total flavonoids in GT extracts were determined. Regarding the total phenolic compounds, the values found vary according to the different edaphoclimatic conditions of the tea plant, the extraction solvent and the methodology used. Moreover, sometime there are some difficulties to compare the results among different studies due to the use of different units to present the results (mg GAE/g extract, mg GAE/L or mg GAE/cup). Lorenzo et al. (2014), for GTE prepared with ethanol, obtained values $390 \mathrm{mg} \mathrm{GAE} / \mathrm{g}$ extract, which is in agreement with the values obtained in the present study. Yin et al. (2012), for extracts dissolved in water obtained the value of $298 \pm 4 \mathrm{mg} \mathrm{GAE} / \mathrm{g}$ extract. On the other hand, Yang et al., 2016a,b, found values of $50.9 \mathrm{mg} \mathrm{GAE} / \mathrm{g}$ extract, for aqueous extracts and subsequently lyophilized.

The methodologies used for the determination of total flavonoids show variations in terms of: quantities of reagents, extract added and the compound used to obtain the calibration line. Most of the studies reported in the literature used catechin as a compound in the calibration curve, which makes it difficult to compare directly with the results of the present study. Oh et al. (2013) and Nibir et al. (2017) obtained values of $29.27 \pm 1.35 \mathrm{mg}$ CTE (catechin equivalents) $/ \mathrm{g}$ extract, and $50.12 \mathrm{mg} \mathrm{CTE} / \mathrm{g}$ extract, respectively, for total flavonoids in GTE.

\subsection{Preparation and characterization of the films}

Initially four samples of green tea were compared regarding their antioxidant capacity and then, just one (commercial GTE) was chosen to be incorporated in the active film due to present the highest antioxidant capacity according to DPPH radical assay, the highest TPC.

First, a PLA/GTE masterbatch mixture was produced to allow the preparation of more homogeneous mixtures that would promote a better dispersion of GTE within the PLA matrix during the extrusion. Afterwards, PLA-based films were produced and, as expected, films containing GTE presented a brownish colour and were less transparent, which was dependent on the amount of GTE added (Fig. 1).

In the FTIR spectrum of the PLA/GTE masterbatch (Fig. 2), it is possible to identify PLA's characteristic vibrational bands, $(\mathrm{C}-\mathrm{H}$ stretching, located at $2994 \mathrm{~cm}^{-1}, 2944 \mathrm{~cm}^{-1}$ and $2881 \mathrm{~cm}^{-1}, \mathrm{C}=\mathrm{O}$ stretching at $1760 \mathrm{~cm}^{-1}$ and the $[\mathrm{C}(\mathrm{O})-\mathrm{O}-\mathrm{C}]$ stretching at $\left.1176 \mathrm{~cm}^{-1}\right)$. It was also possible to identify the presence of GTE through its characteristic vibrational bands, such $(\mathrm{O}-\mathrm{H}$ stretching centered at $3347 \mathrm{~cm}^{-1}, \mathrm{C}=\mathrm{C}$ stretching at $1629 \mathrm{~cm}^{-1}, \mathrm{O}-\mathrm{H}$ bending at $1367 \mathrm{~cm}^{-1}$ and the $\mathrm{C}-\mathrm{O}$ stretching at $1238 \mathrm{~cm}^{-1}$ and $1039 \mathrm{~cm}^{-1}$.

A FTIR analysis was performed to confirm the presence of GTE in the active films (Fig. 3). The FTIR spectra of the extruded films are similar to those obtained in the PLA/GTE masterbatch (Fig. 2). The characteristic peaks of GTE related to $\mathrm{O}-\mathrm{H}$ stretching, centered at $3347 \mathrm{~cm}^{-1}$ are not noticeable on the FTIR spectra of the extruded films. However, it is noticeable the $\mathrm{C}=\mathrm{C}$ stretching vibrational band at $1629 \mathrm{~cm}^{-1}$. The low GTE content in the films (films with $1 \%$ GTE) does not have a high impact on the FTIR spectra.

The mechanical performance and the effect of GTE content of the 

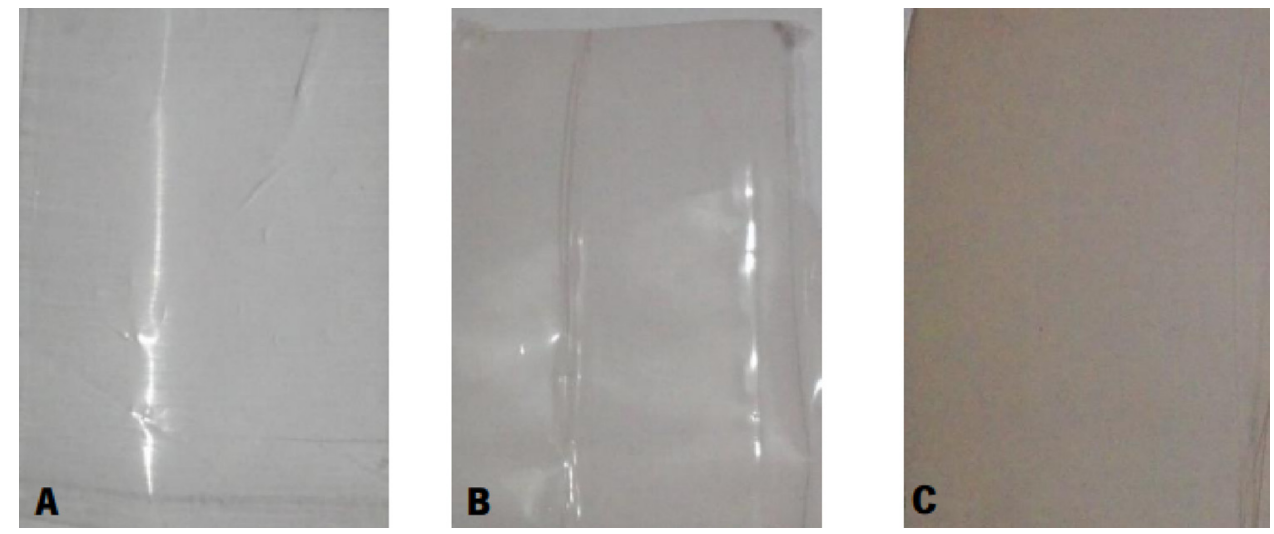

Fig. 1. Visual appearance of the films PLA (neat); PLA 1\% GTE film; PLA 2\% GTE film.

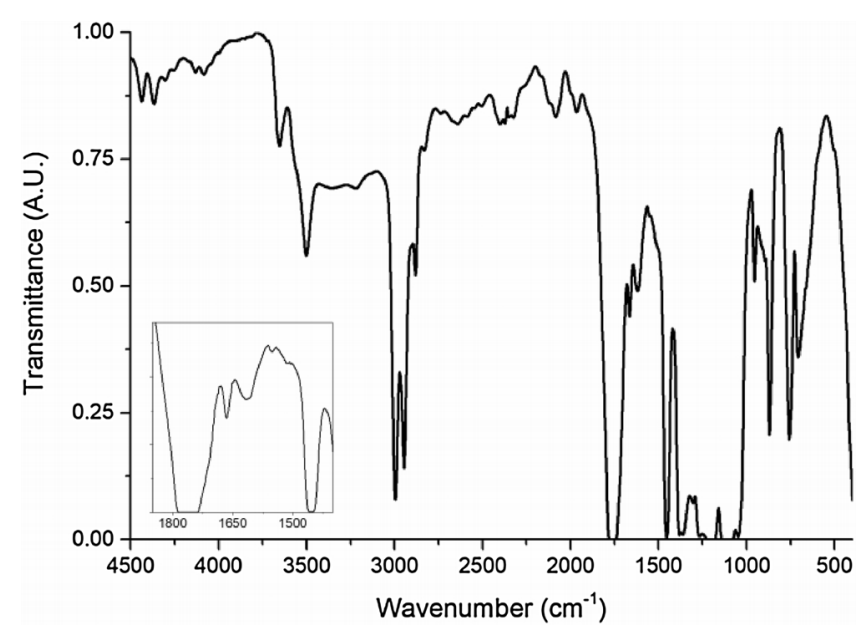

Fig. 2. FTIR spectrum of PLA/GTE masterbatch. The inset was acquired with a resolution of $2 \mathrm{~cm}^{-1}$ to allow a more detailed observation of the GTE's characteristic vibrational bands.

extruded films were evaluated by tensile tests (Table 4).

The incorporation of GTE in the PLA matrix decreased around $12 \%$ the tensile strength for both amounts. The strain at break increased 9.6 and $36 \%$ with the addition of 1 and 2 wt. \% GTE. This can be due to an increase of molecular mobility caused by the addition of GTE.

As it is well documented in the literature, biopolymers, such as PLA have low barrier properties, which limits their applications for packaging, especially on food products that are highly susceptible to $\mathrm{O}_{2}$ or $\mathrm{H}_{2} \mathrm{O}$ (Carrizo et al., 2016).

The water-vapour transmission (WVT) of PLA films was evaluated to understand the influence of GTE on the PLA's barrier properties. The assays were performed following the desiccant method (ASTM E 96/E $96 \mathrm{M}-05$ ), monitoring the desiccant weight until a relative humidity (RH) minimum of $10 \%$ was achieved. The samples' conditions and the WVT rates determined are summarized in Table 5. The results indicate that the addition of higher amounts of GTE improves the PLA's watervapour barrier properties.

Vilarinho et al. (2018) also reported that the incorporation of montmorillonite in a PLA matrix also decreased water permeability. Wu et al. (2013) also reported that the inclusion of GTE in a silver carp skin gelatin films $(0.3 \%$ and $0.7 \%$ GTE) reduced the WVT. The same was reported by Siripatrawan and Harte (2010), when incorporating GTE (among 2-20\% GTE) in chitosan films.

\subsection{Effectiveness of the active films against lipid oxidation}

Four tests were used to monitor the lipid oxidation state of smoked
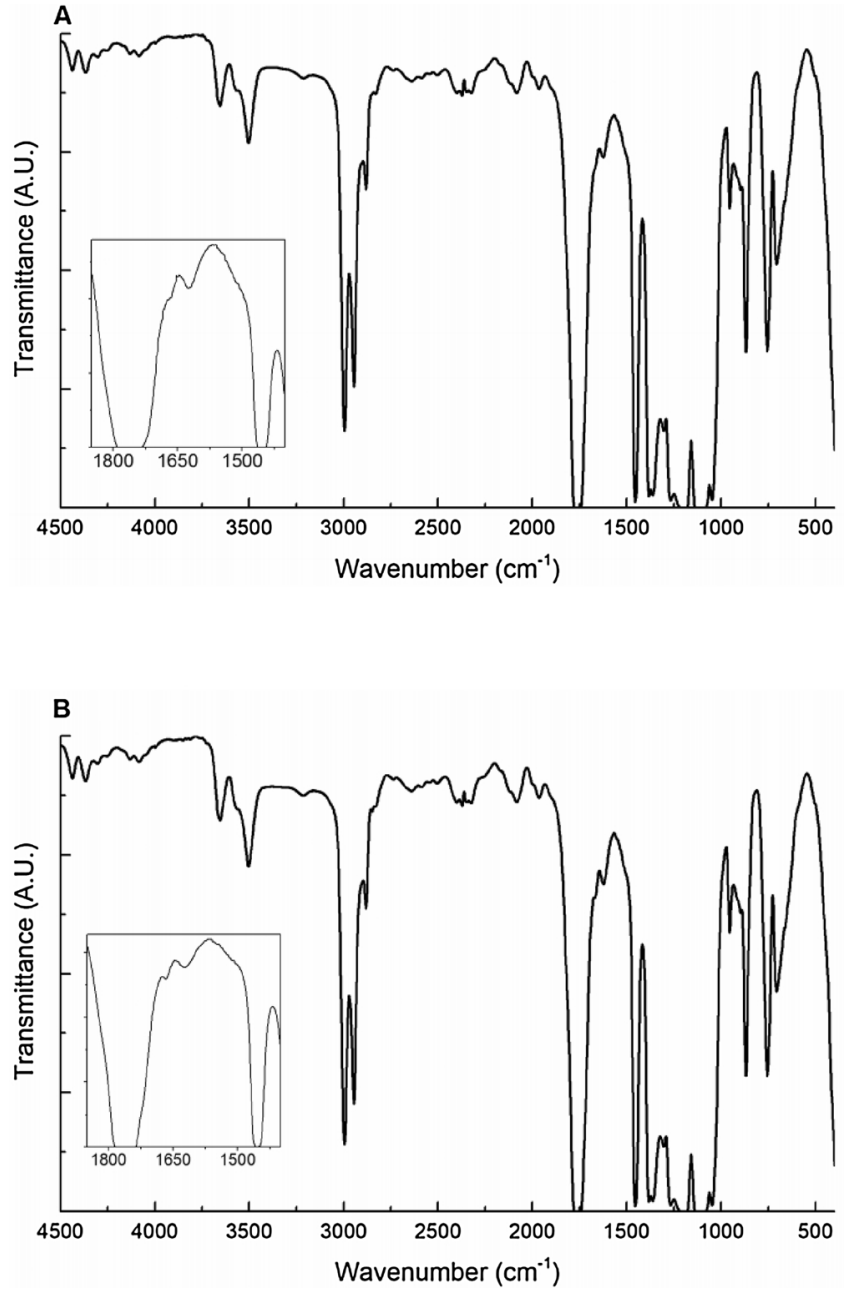

Fig. 3. FTIR spectra of PLA $1 \%$ GTE film (A) and PLA $2 \%$ GTE film (B). The insets were acquired with a resolution of $2 \mathrm{~cm}^{-1}$ to allow a more detailed observation of the GTE's characteristic vibrational bands.

salmon packaged with a PLA/ GTE film and a control film (neat PLA). The tests were performed after $0,7,15,30,45$ and 60 days of contact.

\subsubsection{Determination of peroxide value and p-anisidine value}

Peroxides results from the primary oxidation of oils and fats. The peroxide index is widely used to evaluate the oxidation state of the fat of a given sample. This value gives information on the amount of peroxide present in a sample (Mehta et al., 2015). In the peroxides assay, it 
Table 4

Mechanical properties of the extruded films: tensile strength ( $\sigma$ strength), yield strain ( $\varepsilon$ strain) and strain at break ( $\varepsilon$ break).

\begin{tabular}{llll}
\hline Film & $\sigma$ strength \pm SD $(\mathrm{MPa})$ & $\varepsilon$ strain $\pm \mathrm{SD}(\%)$ & $\varepsilon$ break \pm SD (\%) \\
\hline PLA & $40.2 \pm 8.10$ & $2.42 \pm 0.21$ & $3.63 \pm 0.62$ \\
PLA/ 1\% & $35.4 \pm 1.95$ & $2.49 \pm 0.23$ & $3.98 \pm 0.43$ \\
$\quad$ GTE & & $2.44 \pm 0.12$ & $4.94 \pm 0.34$ \\
$\begin{array}{c}\text { PLA / 2\% } \\
\text { GTE }\end{array}$ & $35.4 \pm 4.06$ & & \\
\hline
\end{tabular}

Table 5

Contact area, films' thickness, WVT rates calculated and their standard deviation (SD). Their results are the mean of three independent replicas.

\begin{tabular}{llll}
\hline Film & $\begin{array}{l}\text { Contact area } \\
\left(\mathrm{m}^{2}\right)\end{array}$ & Film thickness $\pm \mathrm{SD}(\mathrm{mm})$ & WVT $\pm \mathrm{SD}\left(\mathrm{g} \mathrm{h}^{-1} \mathrm{~m}^{-2}\right)$ \\
\hline PLA & 0.038 & $0.047 \pm 0.010$ & $3.35 \pm 0.68$ \\
PLA / 1\% & 0.038 & $0.051 \pm 0.011$ & $2.63 \pm 0.48$ \\
GTE & & $0.078 \pm 0.015$ & $2.18 \pm 0.40$ \\
PLA/2\% & 0.038 & & \\
GTE & & & \\
\hline
\end{tabular}

was found that the peroxide value of smoked salmon was less than $5 \mathrm{meq} / \mathrm{kg}$ over its storage period for both the control and active films (PLA 1\% and PLA 2\%). The highest peroxide value was determined at 30 days storage for the 3 films under study. After this period, at 45 days, the peroxide value decreased on the slices of smoked salmon packed with the control film and the 1\% PLA film. For smoked salmon packed with $2 \%$ PLA film, the peroxide value in this period was similar to that detected at 30 days, proving to be less effective against lipid oxidation than the other films studied. This fact may indicate that a low concentration of GTE is more effective in order to minimize lipid oxidation of smoked salmon. These results are in concordance with the results obtained per Alghazeer et al.(2008) when they investigated the lipid peroxidation, in Atlantic mackerel (Scomber scombrus), in the presence and absence of instant green tea. They verified that a low tea concentration was more effective in controlling oxidation. At 60 days of packaging, no peroxides were detected in the slices of smoked salmon in contact with the active films and with the control film. The decrease in the peroxide index after 45 days can be explained by the fact that possibly after this period the rate of degradation of the hydroperoxides has been higher than its rate of formation since, with in the propagation of the lipid oxidation, the peroxides tend to decompose into by-products or to react with other compounds present in foods (Silva et al., 1999). At 60 days of packaging, no peroxides were detected in the slices of smoked salmon in contact with the active films and with the control film. Georgantelis et al. (2007), also obtained similar results, they observed that the maximum values of peroxides in a storage of fresh sausages for 20 days were reached on day 15, after which, a decline was observed. These results indicate that, at that storage point, it is possible that the rate of decomposition of hydroperoxide is greater than its rate of formation.

The value of $p$-anisidine indicates the presence of aldehydes (secondary oxidation products) formed during the decomposition of peroxides in a sample of fat or oil.

The $p$-anisidine values of the smoked salmon slices in contact with the control film and with active film of PLA 1 and $2 \%$ are shown in Fig. 4.

The results obtained indicate that the lowest $p$-anisidine value was found in smoked salmon packed with the active film PLA 1\% (w/w), demonstrating that the lowest concentration of GT was more effective in inhibiting lipid oxidation, in the slices of smoked salmon, throughout the storage period of 60 days. In contrast, the concentration of $2 \%(\mathrm{w} /$ w) of green tea extract incorporated into the active film after 60 days demonstrated a pro-oxidant effect on smoked salmon slices. In the literature, some authors have already described pro-oxidant activity in tea extracts. For example, Alghazeer et al. (2008), reported that from different concentrations of tea extract tested to inhibit oxidation of frozen mackerel (Scomber combrus), the most effective in controlling oxidation were the lowest.

\subsubsection{Determination of thiobarbituric acid reactive substances (TBARS) values}

The Thiobarbituric Acid Reagent test measures the content of the main aldehyde formed during lipid oxidation of food, malonaldehyde (MDA). It should be noted that MDA is one of the main compounds of the decomposition of the polyunsaturated fatty acids in hydroperoxides formed during the lipid oxidation process.

According to Connell (1995) and Wenjiao et al. (2013), the value of MDA between 1-2 mg MDA/ kg of fish flesh, will normally correspond to a development of an objectionable odour. The results obtained in this assay for smoked salmon in contact with the control films and active PLA films of 1 and 2\%, are shown in Fig. 5. All samples packed with the active films (PLA 1 and 2\%) have MDA content lower than the contents of the samples packed with the control film, except for the slice of smoked salmon packed with film PLA $2 \%$ for 60 days. The results obtained are in accordance with the $p$-anisidine value test, where a high value was also observed at 60 days for smoked salmon packaged with $2 \%$ PLA, demonstrating a pro-oxidant effect of the extract of green tea. These results suggest that PLA film incorporated with 1\% GTE is the most effective to inhibit the lipid oxidation of smoked salmon.

López-de-Dicastillo et al. (2012), developed active antioxidant films for food packaging, through the incorporation of green tea extract into an ethylene vinyl alcohol copolymer (EVOH) matrix. Fillets of sardines in brine were packed with the active film and stored under the light at $4{ }^{\circ} \mathrm{C}$ for 13 days. The lipid oxidation state of the sardines in brine was analyzed by the TBARS assay. During the storage period, the sardine fillets in brine packed with the active film exhibited a reduction of $25 \%$ in the concentration of malonaldehyde. The film with incorporated green tea extract showed to be effective against lipid oxidation.

Yang et al. (2016a,b), analyzed pork packed with protein films with extracts of green tea, oolong tea and black tea incorporated at concentrations of $0.1,0.3$ and $0.5 \%$, stored at $4{ }^{\circ} \mathrm{C}$ for 10 days. The MDA content of pork packed with the active films was lower than that of pork packed with the control film (without tea extracts) during the 10 days of storage. At the end of the storage period, pork packed with the active film with GTE presented $0.93 \mathrm{mg}$ of MDA $/ \mathrm{kg}$ of sample, while pork samples packed with active film with tea extract oolong and pork samples packed with active film with black tea extract presented 1.16 and $1.27 \mathrm{mg}$ of MDA $/ \mathrm{kg}$ of sample, respectively. The sample packed with the active film with GTE, presented both a lower amount of MDA at the end of the storage period and a lower increase of MDA contents during storage than the other samples. Pork wrapped with the active film incorporated with $0.5 \%$ GTE presented a slower lipid oxidation process during storage.

Hong et al. (2009), in turn, produced edible Gelidium corneum-gelatin (GCG) blend films, containing grape fruit seed extract (GFSE) or green tea extract (GTE) and evaluated the quality of pork loins packaged with the film during storage. They found that pork loins packaged with the GCG film containing GFSE or GTE showed a decrease in the TBARS value of 0.38 and $0.59 \mathrm{mg}$ of MDA $/ \mathrm{kg}$ after 10 days of storage, respectively, compared to the control. This allowed to conclude that lipid oxidation in pork loins during storage can be delayed by packing them with the GCF film containing GFSE or GTE.

Siripatrawan and Noiha (2012), used as active packaging, chitosan film incorporating green tea extract (CGT-film), for shelf life extension of pork sausages. The pork sausages wrapped with CGT-film and pork sausages wrapped with C-film (chitosan alone-film), were stored at $4{ }^{\circ} \mathrm{C}$. It was found that samples wrapped with CGT-film showed lower changes in TBA value than those wrapped with C-film and control. The results suggested that incorporation of GTE into chitosan film could 


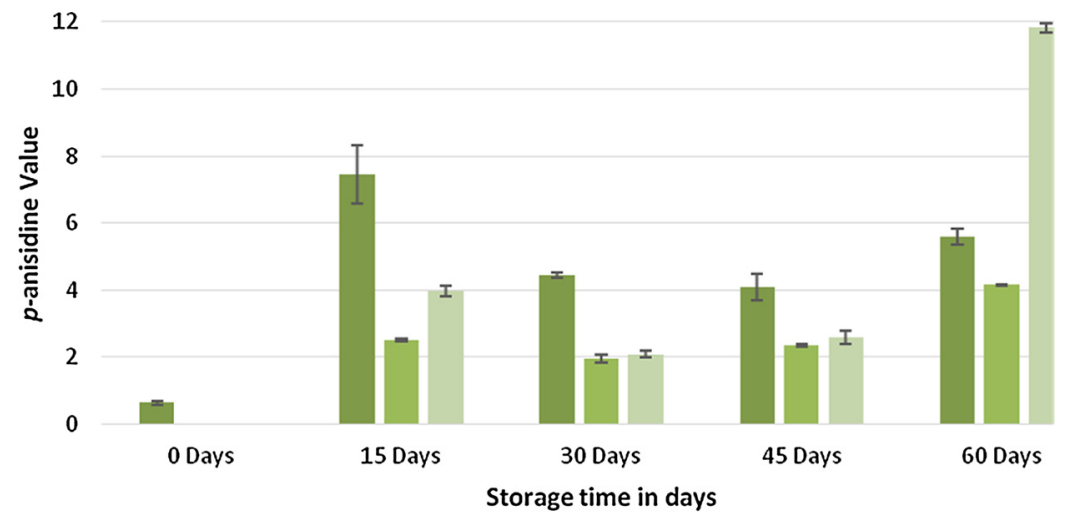

Control Film $\square$ PLA/Green Tea $1 \%$ Film $\square$ PLA/Green Tea $2 \%$ Film

Fig. 4. Results of the $p$-anisidine assay for smoked salmon in contact with the control films, active film PLA $1 \%$ (w/w) and active film PLA $2 \%$ (w/w).

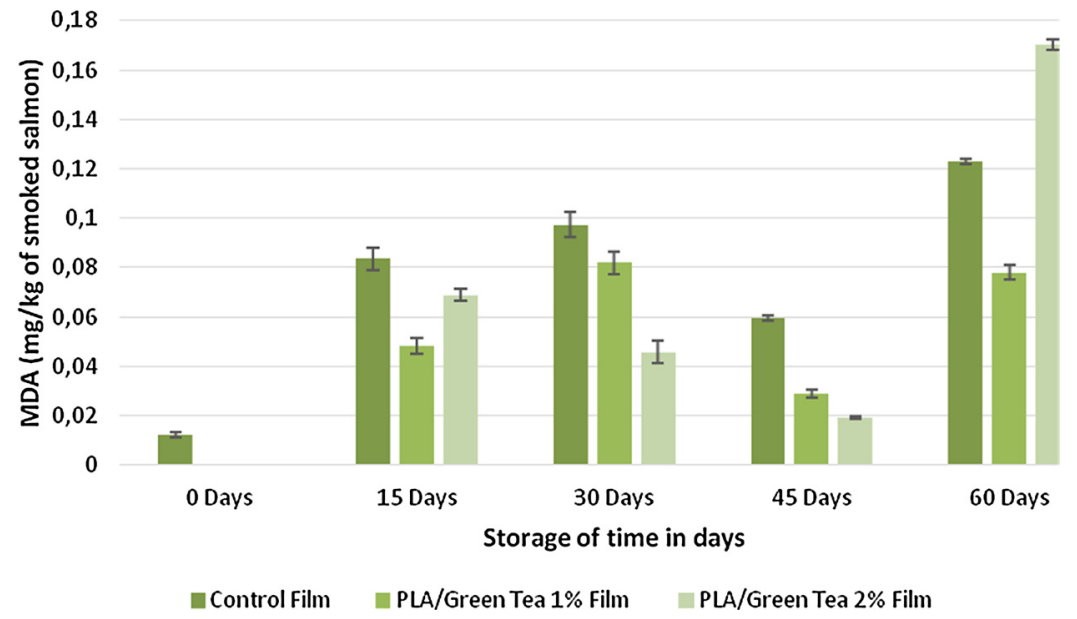

Fig. 5. Results of the TBARS assay for smoked salmon in contact with the control films, active film PLA $1 \%$ (w/w) and active film PLA $2 \%$ (w/w).

enhance the antioxidant properties of the film and thus maintained the qualities and prolonged the shelf life of the sausages.

\subsubsection{Determination of hexanal}

The main volatile components formed during the process of lipid oxidation of foods are aldehydes, and are therefore widely used to measure the progress of lipid oxidation. The hexanal is the dominant aldehyde formed in the course of the same, being considered an indicator of the lipid oxidation.

Regarding the results obtained for smoked salmon in contact with the control films and active PLA films 1 and $2 \%$, it was verified that the hexanal has not been detected in most of the tests performed. In the case of the control film, the presence of hexanal was only detected after 45 days of storage $(170.9 \mu \mathrm{g}$ hexanal $/ 100 \mathrm{~g})$, verifying a reduction on the value over the 60 days of storage $(104.7 \mu \mathrm{g}$ hexanal/100 g). In the slices of smoked salmon in contact with the active films, the presence of hexanal was detected only at the end of the 60 days of storage, and the highest hexanal value was detected in the smoked salmon packed with the active film PLA $2 \%(107.4 \mu \mathrm{g}$ hexanal $/ 100 \mathrm{~g})$. The results of this study do not allow concluding about the protective activity of the active films with GTE in relation to the control film at 60 days, however, in the literature, studies report the efficacy of the extract against lipid oxidation, through the determination of hexanal. For example, the study by (Alghazeer et al. (2008), previously mentioned for the TBARS assay, also analyzed the formation of hexanal in Atlantic mackerel with incorporated GTE, in the concentrations of $250 \mathrm{mg} / \mathrm{kg}$ and $500 \mathrm{mg} / \mathrm{kg}$. The authors verified that hexanal levels significantly increased after 16 weeks of storage in the control sample (without addition of GTE) stored at $-10{ }^{\circ} \mathrm{C}$ relative to the sample with $250 \mathrm{mg} / \mathrm{kg}$ of incorporated GTE, stored at the same temperature, showing that the addition of GTE to the food delayed the lipid oxidation process.

\section{Conclusion}

Aiming to investigate the use of GTE in active packaging, four different GTE regarding antioxidant capacity were studied. The results demonstrated a high antioxidant capacity of GTE, which confirms its great potential to be incorporated into food packaging in order to produce active food packaging with antioxidant properties based on natural compounds. Thus, a new antioxidant active packaging material for food has been developed, consisting of a PLA film in which different concentrations of 1 and $2 \%(w / w)$ of GTE have been incorporated.

PLA/GTE films were produced by blown extrusion. The mechanical properties of the produced films were similar when compared to PLA films. Regarding the films' barrier properties, in particular the watervapor transmission, the addition of higher amounts of GTE decreased the WVT rate, thus improving the PLA's barrier efficiency to $\mathrm{H}_{2} \mathrm{O}$.

The effectiveness of GTE active films in retarding lipid oxidation of a model fatty food (smoked salmon) was evaluated by four methods: peroxides value, $p$-anisidine value, Thiobarbituric Active Reactive Substances (TBARS) assay and hexanal monitoring.

The results showed that incorporation of GTE in PLA films protects smoked salmon from lipid oxidation and 1\% GTE was found to be more effective than $2 \%$ GTE.

The presence of GTE in the PLA can reduce the lipid oxidation of high-lipid content fish products, suggesting that it can be considered a 
good alternative to conventional plastics. However, additional studies should be performed to better understand the GTE mechanism of action as the results suggest a pro-oxidant effect of PLA/GTE $2 \%$ after 60 days of storage; to evaluate the antimicrobial capacity of the new active films namely regarding pathogens like Listeria monocytogenes, Escherichia coli 0157:H7 and Salmonella enterica.

\section{Acknowledgments}

This work was funded by FEDER, through the Program INTERREG V A España Portugal (POCTEP), by the Project 0377_IBERPHENOL_6_E.

\section{References}

Albertos, I., Avena-Bustillos, R.J., Martín-Diana, A.B., Du, W.-X., Rico, D., McHugh, T.H., 2016. Antimicrobial olive leaf gelatin films for enhancing the quality of cold smoked Salmon. Ind. Crops Prod. 94, 800-811.

Alghazeer, R., Saeed, S., Howell, N.K., 2008. Aldehyde formation in frozen mackerel (Scomber scombrus) in the presence and absence of instant green tea. Food Chem. 108, 801-810. http://dx.doi.org/10.1016/j.foodchem.2007.08.067.

AOCS, 2003. AOCS Official Method Cd 8-53, Peroxide Value Acetic Acid-Chloroform Method [WWW Document]. URL:. https://wenku.baidu.com/view/ 1079b757ad02de80d4d8403f.html.

Assis, R.Q., Lopes, S.M., Costa, T.M.H., Flôres, S.H., Rios, A.D.O., 2017. Active biodegradable cassava starch films incorporated lycopene nanocapsules. Ind. Crops Prod. $109,818-827$.

ASTMASTM E 96/E 96M-05 - Standard Test Methods for Water Vapor Transmission of Materials, Philadelphia, 2005, n.d.

ASTM - American Standard Testing and Material; ASTM D882/02: Standard Test Method for Tensile Properties of Thin Plastic Sheeting, New York, 2002, n.d.

Baek, S.-K., Song, K.B., 2018. Development of Gracilaria vermiculophylla extract films containing zinc oxide nanoparticles and their application in smoked salmon packaging. LWT - Food Sci. Technol. 89, 269-275.

Basnet, S., Otsuka, M., Sasaki, C., Asada, C., Nakamura, Y., 2015. Functionalization of the active ingredients of Japanese green tea (Camellia sinensis) for the synthesis of biobased epoxy resin. Ind. Crops Prod. 73, 63-72.

Biji, K.B., Ravishankar, C.N., Mohan, C.O., Srinivasa Gopal, T.K., 2015. Smart packaging systems for food applications: a review. J. Food Sci. Technol. 52, 6125-6135. http:// dx.doi.org/10.1007/s13197-015-1766-7.

Bligh, E., Dyer, W., 1959. Can. J. Biochem. Physiol. 37, 911-917.

Broekaert, K., Vlaemynck, G., Heyndrickx, M., 2017. Microbial ecology of seafoods: a special emphasis on the spoilage microbiota of North Sea seafood. In: A, de S. Sant'Ana, Sons, J.W. (Eds.), Quantitative Microbiology in Food Processing: Modeling the Microbial Ecology, pp. 499-518.

BSI, 1998. British Standard Method 684-2.24:1998; Methods of Analysis of Fats and Fatty Oils - determination of Anisidine Value.

Cardoso, L.G., Pereira Santos, J.C., Camilloto, G.P., Miranda, A.L., Druzian, J.I., Guimarães, A.G., 2017. Development of active films poly (butylene adipate co-terephthalate) - PBAT incorporated with oregano essential oil and application in fish fillet preservation. Ind. Crops Prod. 108, 388-397.

Carrizo, D., Gullo, G., Bosetti, O., Nerín, C., 2014. Development of an active food packaging system with antioxidant properties based on green tea extract. Food Addit. Contam. Part A 31, 364-373, http://dx doi.org/10.1080/19440049.2013.869361.

Carrizo, D., Taborda, G., Nerín, C., Bosetti, O., 2016. Extension of shelf life of two fatty foods using a new antioxidant multilayer packaging containing green tea extract. Innov. Food Sci. Emerg. Technol. 33, 534-541. http://dx.doi.org/10.1016/j.ifset. 2015.10.018.

Connell, J.J., 1995. Control of Fish Quality, 4th ed. Wiley-Blackwell.

Crizel, T.M., Costa, T.M.H., Simone, A.O.R., Flôresa, H., 2016. Valorization of food-grade industrial waste in the obtaining active biodegradable films for packaging. Ind. Crops Prod. 87, 218-228.

Erkan, N., Ayranci, G., Ayranci, E., 2008. Antioxidant activities of rosemary (Rosmarinus Officinalis L.) Extract, blackseed (Nigella sativa L.) essential oil, carnosic acid, rosmarinic acid and sesamol. Food Chem. 110, 76-82. http://dx.doi.org/10.1016/j. foodchem.2008.01.058.

Geetha, S., Sai Ram, M., Sing, V., LLavazhargan, R.C., 2003. Evaluation of antioxidant activity of leaf extract of Seabuckthorn (Hippophae rhamnoides L.) on chromium(VI) induced oxidative stress in albino rats. J. Ethnopharmacol. 87, 247-251. http://dx. doi.org/10.1016/S0378-8741(03)00154-5.

Georgantelis, D., Ambrosiadis, I., Katikou, P., Blekas, G., Georgakis, S.A., 2007. Effect of rosemary extract, chitosan and $\alpha$-tocopherol on microbiological parameters and lipid oxidation of fresh pork sausages stored at $4^{\circ} \mathrm{C}$. Meat Sci. 76, 172-181. http://dx.doi. org/10.1016/j.meatsci.2006.10.026.

Giménez, B., López de Lacey, A., Pérez-Santín, E., López-Caballero, M.E., Montero, P., 2013. Release of active compounds from agar and agar-gelatin films with green tea extract. Food Hydrocoll. 30, 264-271. http://dx.doi.org/10.1016/j.foodhyd.2012. 05.014.

Gutiérrez, R.M.P., Luna, H.H., Garrido, S.H., 2006. Antioxidant activity of tagetes erecta essential oil. J. Chil. Chem. Soc. 51, 883-886. http://dx.doi.org/10.4067/S0717 97072006000200010

Hatami, T., Emami, S.A., Miraghaee, S.S., Mojarrab, M., 2014. Total phenolic contents and antioxidant activities of different extracts and fractions from the aerial parts of Artemisia biennis willd. Iran. J. Pharm. Res. IJPR 13, 551-559.

Hong, Y.-H., Lim, G.-O., Song, K.B., 2009. Physical properties of gelidium corneum -gelatin blend films containing grapefruit seed extract or Green tea extract and its application in the packaging of pork loins. J. Food Sci. 74, C6-C10. http://dx.doi.org/ 10.1111/j.1750-3841.2008.00987.x.

Jamshidian, M., Tehrany, E.A., Imran, M., Jacquot, M., Desobry, S., 2010. Poly-lactic acid: production, applications, nanocomposites, and release studies. Compr. Rev. Food Sci. Food Saf. 9, 552-571. http://dx.doi.org/10.1111/j.1541-4337.2010. 00126.x.

Kuskoski, E.M., Asuero, A.G., Morales, M.T., Fett, R., 2006. Frutos tropicais silvestres e polpas de frutas congeladas: atividade antioxidante, polifenóis e antocianinas. Ciência Rural 36, 1283-1287. http://dx.doi.org/10.1590/S010384782006000400037.

Lee, L.S., Kim, S.H., Kim, Y.B., Kim, Y.C., 2014. Quantitative analysis of major constituents in green tea with different plucking periods and their antioxidant activity. Molecules 19, 9173-9186. http://dx.doi.org/10.3390/molecules19079173.

López de Dicastillo, C., Castro-López, M., del, M., López-Vilariño, J.M., GonzálezRodríguez, M.V., 2013. Immobilization of green tea extract on polypropylene films to control the antioxidant activity in food packaging. Food Res. Int. 53, 522-528. http://dx.doi.org/10.1016/j.foodres.2013.05.022.

López de Dicastillo, C., Nerín, C., Alfaro, P., Catalá, R., Gavara, R., Hernández-Muñoz, P., 2011. Development of New antioxidant active packaging films based on ethylene vinyl alcohol copolymer (EVOH) and Green tea extract. J. Agric. Food Chem. 59, 7832-7840. http://dx.doi.org/10.1021/jf201246g.

López de Lacey, A.M., López-Caballero, M.E., Montero, P., 2014. Agar films containing green tea extract and probiotic bacteria for extending fish shelf-life. LWT - Food Sci. Technol. 55, 559-564. http://dx.doi.org/10.1016/j.lwt.2013.09.028.

López-de-Dicastillo, C., Gómez-Estaca, J., Catalá, R., Gavara, R., Hernández-Muñoz, P., 2012. Active antioxidant packaging films: development and effect on lipid stability of brined sardines. Food Chem. 131, 1376-1384. http://dx.doi.org/10.1016/j. foodchem.2011.10.002.

Lorenzo, J.M., Munekata, P.E.S., 2016. Phenolic compounds of green tea: health benefits and technological application in food. Asian Pac. J. Trop. Biomed. 6, 709-719. http://dx.doi.org/10.1016/j.apjtb.2016.06.010.

Lorenzo, J.M., Sineiro, J., Amado, I.R., Franco, D., 2014. Influence of natural extracts on the shelf life of modified atmosphere-packaged pork patties. Meat Sci. 96, 526-534. http://dx.doi.org/10.1016/j.meatsci.2013.08.007.

Lyu, F., Gao, F., Din, Y., 2018. Effects of gamma radiation combined with cinnamon oil on qualities of smoked salmon slices inoculated with Shewanella putrefaciens. Food Sci Nutr. 1-8.

Marsh, K., Bugusu, B., 2007. Food packaging - roles, materials, and environmental issues. J. Food Sci. 72, R39-R55. http://dx.doi.org/10.1111/j.1750-3841.2007.00301.x.

Martín-Diana, A.B., Rico, D., Barry-Ryan, C., 2008. Green tea extract as a natural antioxidant to extend the shelf-life of fresh-cut lettuce. Innov. Food Sci. Emerg. Technol. 9, 593-603. http://dx.doi.org/10.1016/j.ifset.2008.04.001.

Martinsdóttir, E., Sveinsdóttir, K., Pennanen, K., Heiniö, R.-L., 2014. Enriched Convenience Seafood Products - Nordic Innovation. Oslo.

Mehta, B.M., Darji, V.B., Aparnathi, K.D., 2015. Comparison of five analytical methods for the determination of peroxide value in oxidized ghee. Food Chem. 185, 449-453. http://dx.doi.org/10.1016/j.foodchem.2015.04.023.

Miller, D.D., 1998. Food Chemistry: A Laboratory Manual, 2nd ed. Wiley Scrivenner, Canada.

Moure, A., Cruz, J.M., Franco, D., Domínguez, J.M., Sineiro, J., Domínguez, H., José Núñez, M., Parajó, J.C., 2001. Natural antioxidants from residual sources. Food Chem. 72, 145-171. http://dx.doi.org/10.1016/S0308-8146(00)00223-5.

Muriel-Galet, V., Cran, M.J., Bigger, S.W., Hernández-Muñoz, P., Gavara, R., 2015. Antioxidant and antimicrobial properties of ethylene vinyl alcohol copolymer films based on the release of oregano essential oil and green tea extract components. J. Food Eng. 149, 9-16. http://dx.doi.org/10.1016/j.jfoodeng.2014.10.007.

Nibir, Y.M., Sumit, A.F., Akhand, A.A., Ahsan, N., Hossain, M.S., 2017. Comparative as sessment of total polyphenols, antioxidant and antimicrobial activity of different tea varieties of Bangladesh. Asian Pac. J. Trop. Biomed. 7, 352-357. http://dx.doi.org/ 10.1016/j.apjtb.2017.01.005.

Oh, J., Jo, H., Cho, A.R., Kim, S.-J., Han, J., 2013. Antioxidant and antimicrobial activities of various leafy herbal teas. Food Control 31, 403-409. http://dx.doi.org/10. 1016/j.foodcont.2012.10.021.

Pateiro, M., Lorenzo, J.M., Amado, I.R., Franco, D., 2014. Effect of addition of green tea, chestnut and grape extract on the shelf-life of pig liver pâté. Food Chem. 147, 386-394. http://dx.doi.org/10.1016/j.foodchem.2013.09.153.

Paul, M.-A., Alexandre, M., Degée, P., Henrist, C., Rulmont, A., Dubois, P., 2003. New nanocomposite materials based on plasticized poly(l-lactide) and organo-modified montmorillonites: thermal and morphological study. Polym. (Guildf) 44, 443-450. http://dx.doi.org/10.1016/S0032-3861(02)00778-4.

Peron, A.P., Marcos, M.C., Cardoso, S.C., Vicentini, V.E.P., 2008. Cytotoxic potencial evaluation from the Camellia sinensis and Cassia angustifolia Vahl teas, in vegetal test system. Arq. Ciênc. Saúde Unipar 12, 51-54.

Perumalla, A.V.S., Hettiarachchy, N.S., 2011. Green tea and grape seed extracts - potential applications in food safety and quality. Food Res. Int. 44, 827-839. http://dx. doi.org/10.1016/j.foodres.2011.01.022.

Regulation (EC) No 1935/2004, 2004. Off. J. Eur. Union L338/4-L338/17.

Regulation (EC) No 450/2009, 2009. Off. J. Eur. Union L135/3-L135/11.

Ribeiro-Santos, R., de Melo, N.R., Andrade, M., Azevedo, G., Machado, A.V., CarvalhoCosta, D., Sanches-Silva, A., 2017. Whey protein active films incorporated with a blend of essential oils: characterization and effectiveness. Packag. Technol. Sci. http://dx.doi.org/10.1002/pts.2352. 
Sampels, S., 2013. Oxidation and Antioxidants in Fish and Meat from Farm to Fork. Food Industry. InTech, pp. 115-144. http://dx.doi.org/10.5772/53169.

Sanches Silva, A., Cruz Freire, J.M., Sendón, R., Franz, R., Losada, P.P., 2009. Migration and diffusion of diphenylbutadiene from packages into foods. J. Agric. Food. Chem. 57 (21), 10225-10230. http://dx.doi.org/10.1021/jf901666h.

Silva, F.A.M., Borges, M.F.M., Ferreira, M.A., 1999. Métodos para avaliação do grau de oxidação lipídica e da capacidade antioxidante. Quim. Nova 22, 94-103. http://dx. doi.org/10.1590/S0100-40421999000100016.

Silva, A.S., Freire, J.M.C., Franz, R., Losada, P.P., 2008. Mass transport studies of model migrants within dry foodstuffs. J. Cereal Sci. 48 (3), 662-669. http://dx.doi.org/10. 1016/j.jcs.2008.02.006.

Siripatrawan, U., Harte, B.R., 2010. Physical properties and antioxidant activity of an active film from chitosan incorporated with green tea extract. Food Hydrocoll. 24, 770-775. http://dx.doi.org/10.1016/j.foodhyd.2010.04.003.

Siripatrawan, U., Noipha, S., 2012. Active film from chitosan incorporating green tea extract for shelf life extension of pork sausages. Food Hydrocoll. 27, 102-108. http:// dx.doi.org/10.1016/j.foodhyd.2011.08.011.

Theivendran, S., Hettiarachchy, N.S., Johnson, M.G., 2006. Inhibition of listeria monocytogenes by nisin combined with grape seed extract or Green tea extract in soy protein film coated on Turkey frankfurters. J. Food Sci. 71, M39-M44. http://dx.doi. org/10.1111/j.1365-2621.2006.tb08905.x.

Vilarinho, F., Andrade, M., Buonocore, G.G., Stanzione, M., Vaz, M.F., Sanches Silva, A., 2018. Monitoring lipid oxidation in a processed meat product packaged with nanocomposite poly(lactic acid) film. Eur. Polym. J. 98, 362-367. http://dx.doi.org/10. 1016/j.eurpolymj.2017.11.034.

Wen, J., Morrissey, P.A., Walton, J., Sheehy, P.J., 1997. Rapid and quantitative determination of hexanal in cooked muscle foods. Ir. J. Agric. Food Res. 36, 75-84.

Wenjiao, F., Yongkui, Z., Pan, D., Yuwen, Y., 2013. Effects of chitosan coating containing antioxidant of bamboo leaves on qualitative properties and shelf life of silver carp during chilled storage. Czech J. Food Sci. 31, 451-456.
Wrona, M., Cran, M.J., Nerín, C., Bigger, S.W., 2017. Development and characterisation of HPMC films containing PLA nanoparticles loaded with green tea extract for food packaging applications. Carbohydr. Polym. 156, 108-117. http://dx.doi.org/10. 1016/j.carbpol.2016.08.094.

Wu, J., Chen, S., Ge, S., Miao, J., Li, J., Zhang, Q., 2013. Preparation, properties and antioxidant activity of an active film from silver carp (Hypophthalmichthys molitrix) skin gelatin incorporated with green tea extract. Food Hydrocoll. 32, 42-51. http:// dx.doi.org/10.1016/j.foodhyd.2012.11.029.

Yam, K.L., Takhistov, P.T., Miltz, J., 2005. Intelligent packaging: concepts and applications. J. Food Sci. 70, R1-R10. http://dx.doi.org/10.1111/j.1365-2621.2001. tb16112.x.

Yang, H.-J., Lee, J.-H., Won, M., Song, K., Bin, 2016a. Antioxidant activities of distiller dried grains with solubles as protein films containing tea extracts and their application in the packaging of pork meat. Food Chem. 196, 174-179. http://dx.doi.org/ 10.1016/j.foodchem.2015.09.020.

Yang, W., Owczarek, J.S., Fortunati, E., Kozanecki, M., Mazzaglia, A., Balestra, G.M., Kenny, J.M., Torre, L., Puglia, D., 2016b. Antioxidant and antibacterial lignin nanoparticles in polyvinyl alcohol/chitosan films for active packaging. Ind. Crops Prod. 94, 800-811.

Yin, J., Becker, E.M., Andersen, M.L., Skibsted, L.H., 2012. Green tea extract as food antioxidant. Synergism and antagonism with $\alpha$-tocopherol in vegetable oils and their colloidal systems. Food Chem. (135), 2195-2202. http://dx.doi.org/10.1016/j. foodchem.2012.07.025.

Yoo, K.M., Lee, C.H., Lee, H., Moon, B., Lee, C.Y., 2008. Relative antioxidant and cytoprotective activities of common herbs. Food Chem. 106, 929-936. http://dx.doi.org/ 10.1016/j.foodchem.2007.07.006.

Yu, Z., Sun, L., Wang, W., Zeng, W., Mustapha, A., Lin, M., 2018. Soy protein-based films incorporated with cellulose nanocrystals and pine needle extract for active packaging. Ind. Crops Prod. 112, 412-419. 